\title{
Competitive Advantages and Performance of Stock Market: The Case of Egypt
}

\author{
Nader Alber ${ }^{1}$ \\ ${ }^{1}$ Faculty of Commerce-Ain Shams University, Cairo, Egypt \\ Correspondence: Nader Alber, Faculty of Commerce-Ain Shams University, Cairo, Egypt. Tel: 20-100-566-8507. \\ E-mail: naderalberfanous@yahoo.com
}

\author{
Received: June 11, 2013 \\ Accepted: October 9, 2013 \\ Online Published: October 26, 2013 \\ doi:10.5539/ijef.v5n11p133 \\ URL: http://dx.doi.org/10.5539/ijef.v5n11p133
}

\begin{abstract}
This paper aims at analyzing the effects of quality announcement on performance of Egyptian listed companies. This has been conducted by event study methodology using announcements of international and national quality accreditation during the period from 2006 to 2012 .

Abnormal Returns (ARs) are the differences between actual returns and estimated (normal) returns. It's argued that good informational content may lead to positive abnormal returns.

Results indicate that, hypotheses regarding the significance of differences between ARs with an estimation period of 30 days and a window from day -10 to day +10 could be accepted. Also, robustness check using CARs assures this significance. Findings show that informational content of competitive advantages has a positive effect on abnormal return of listed companies in the Egyptian exchange.
\end{abstract}

Keywords: cross listing, Egyptian exchange, event study, quality announcement

\section{Introduction}

Competitive advantages give a company an ability to generate greater operational or marketing advantages that may enhance the overall performance of the firm. Competitive

advantages could be comparative or differential. Comparative advantage concerns with firm's ability to produce its products at a lower cost than its competitors while differential advantage focuses on firm's ability to produce at a better quality compared with its competitors.

Competitive advantage has been elaborated by many scholars, from Porter (1985) to McGrath (2013). Porter (1985) addresses competitive advantage as the ability gained through attributes and resources to perform at a higher level than others in the same industry or market. McGrath (2013) argues that Porter's Five Forces Analysis is redundant as competition comes not just from cheap substitutes but from a change in perception in the wider marketplace through continuous reconfiguration, healthy disengagement, using resource allocation to promote deftness, building an innovation proficiency, leadership and mid-set and personal meaning of transient advantage.

Having competitive advantages reflects a higher level of quality that requires a higher level of standards. Pioneer thinkers such as Deming (1982) and Juran (1982) urged companies in the U.S. to incorporate quality as an integral part of their operations. In the 1980s, the BS 5750 standards became the cornerstone for national quality in England; and many other countries. In the US, this standard was developed and released as the American National Standards Institute (ANSI) ANSI 90 series of quality standards.

According to Davis (1997), standards are of two types: 1-Standards of uniformity, that describes the means used to ensure that the product has the required characteristics. 2-Functional standards, those define the characteristics of the final product. Also, Sandholm (2000) addresses 6 types of standards: Terminology, Basic, Dimensional, Performance, Testing and inspection, and Quality system standards.

Benefits of standards could by indicated by their role in overcoming certain key problems; such as improving safety, preventing diseases, economic allocation of scarce materials, reducing costs, marketing function , assuring a minimum level of quality and customers' confidence, penetrating new markets, transferring of technical knowledge, and enhancing profitability. 
According to Hesham \& Curry 2003), organizations that provide standards for many industries can be classified into the following: 1-Trade associations: these are generally composed of various companies in the same business, serving a specific industry. 2-Professional societies: these organizations existed mostly prior to the major standardization efforts. 3-The third type is those organizations that are specially created for the purpose of developing standards.

Sandholm (2000) explains that developing countries can gain by adopting international standards as national standards, as the process of standards development is time-consuming and costly, and that many developing countries do not have the professional recourses necessary to prepare standards in certain areas.

In relevance to this issue, standards, more specifically, ISO 9000 articulates the information relevant to quality and thereby ensuring consistency, and indirectly, enhancing the firms' reputation for quality. So, there has been a growing realization among business and manufacturing companies from all areas of human endeavor, to register for ISO 9000 or an industry-specific version QS 9000, AS 9100, ISO 9000:2000 and/or ISO 14000 (Corbett \& Kirsch, 2001).

Aarts \& Vose (2001) has established that firms that have implemented ISO standards managed to accomplish continuous enhancements and improvements, profit improvement, and marketing benefits. Lee \& Palmer (1999) examines the effects of firms size and finds that perceived performance of companies improves significantly after implementing ISO 9000 quality programmes (for both small and large companies).

Quality accreditation has been elaborated in terms of its marketing and operational characteristics rather than its financial potential effects, and this is why, this paper tries to fill this gab. This paper addresses the following major question: How does the Egyptian stock market reflect the informational contents, regarding quality competitive advantages?

Therefore, research problem can be defined by presenting the abnormal returns of Egyptian listed companies which have quality competitive advantages, before having them compared with those of after having these advantages. Concerning with anticipated differences in performance indicators due to the informational content of quality competitive advantages, the research aims to determine whether these differences are significant or not?

The key goal of this paper is to evaluate the impact of having quality competitive advantages, concerning with ISO accreditation and other quality awards (as international accreditation). Also, it tries to address the effect of cross listing as Global Depositary Receipts GDR and listing in S\&P/EGX ESG (as national accreditation). This evaluation is conducted for listed companies in Egyptian exchange.

Cross listing means the listing of a company's common shares on an exchange that is different than its original exchange. This requires meeting the same requirements as any other listed member of the exchange, such as accounting policies and filing requirements.

This paper tries to shed a light for the policy makers, governments and academic organizations to see how quality competitive advantages may affect the profitability of the stockholders in the Egyptian exchange. The research significance is relevant to the analysis of this anticipated impact, which may help in rationalizing the decisions of the above-mentioned organizations.

In brief, this study tries to answer these main questions:

Does "ISO accreditation" announcement affect abnormal returns of Egyptian listed companies?

Does "quality awards" announcement affect abnormal returns of Egyptian listed companies?

Does "cross listing" announcement affect abnormal returns of Egyptian listed companies?

Does "listing in S\&P/EGX ESG" announcement affect abnormal returns of Egyptian listed companies?

The paper is arranged as follows: after this introduction, section 2 reviews research literature that has concerned with "quality competitive advantages", as measured by quality accreditation and cross listing. Section 3 explains research methodology and illustrates how to test the hypotheses. Section 4 is for empirical work, presenting results, discussing how these results answer research questions and illustrating robustness checks. Section 5 summarizes the paper and provides remarks about conclusions.

\section{Literature Review}

This section tries to present some of previous work, which has been conducted in the field of the financial effects of quality competitive advantages, concerning with quality accreditation and cross listing.

The effects of quality announcement on financial performance have consistently supported the proposition that 
better quality has a positive impact on business performance. Chapman et al (1997) finds that improved financial performance (sales per employee) was linked to greater integration of quality plans into strategic business plans. This relationship is found to be stronger in service firms than in manufacturing ones as applied on large service and manufacturing firms in Australia. .

Mo \& Chan (1997) divides benefits of implementing ISO 9000 into quantitative or non-quantitative terms. Quantitative benefits include, expanding market share, reduce scrape rate, increasing productivity and reduce product defect rate. Non-quantitative benefits include increase employee morale; improving customer satisfaction, better control of suppliers, and improving existing system.

Elmuti et al (1997) shows that quality announcement may affect the increasing of stock prices. Another study by Rao et al (1997) indicates that ISO 9000 registered companies exhibit superior levels of quality assurance, strategic quality planning, and profitability. Also, Easton \& Jarrell (1998) conducts an event study to show a significant improvement in performance after implementing TQM.

Docking \& Dowen (1999) finds that small firms in the US experience positive stock market reaction to the announcement of their first ISO 9000 certification, but that large firms' stock prices don't respond. Haversjo (2000) discusses the financial effects of ISO 9000 registration for Danish companies. The study indicates that registration provided positive results, as measured by companies' rate of return. Besides, Casadesús et al. (2000) finds that Basque companies report substantial operational and financial benefits from certification.

To the contrary, a research by Aarts and Vos (2001) investigates the ISO's impact on New Zealand firms financial performance and finds that: a) ISO certification announcement has not effect on firms stock value, b) ISO certified companies demonstrate inferior performance when compared to the market on average, and c) the choice of certifying authority holds importance to the success of implementation.

Dimara et al (2002) identifies the effects of adopting ISO 9000 on a wide range of financial performance indices. Results indicate that the expected benefits of ISO 9000 implementation may vary depending on the strategic orientation of the firm. For firms perusing a cost leadership strategy, ISO 9000 has a positive impact on the profitability indices. For firms pursuing a market differentiation strategy, ISO 9000 resulted in a growth of sales. However, firms adopting a focus strategy don't benefit from ISO 9000 implementation. The study stressed the importance of link between strategic orientation and benefits of ISO implementation.

Wayhan et al (2002) addresses a main question about whether ISO certification really led to superior financial performance in 48 small to medium USA firms. The analytical model tests differences in performance indicators over the period of 1990-98 using Multivariate Analysis of Variance (MANOVA). The findings indicate that ISO certification doesn't generate additional sales, doesn't enhance profitable revenues growth and doesn't have a positive impact on profitability.

Heras et al (2002) investigates the links between quality certification and improved financial performance in 400 accredited and 400 non accredited companies in Spain over the period 1994-1998. Results indicate that certification to ISO 9000 is associated with better financial performance since certified firms show superior ROA than non-certified companies. Also, Nicolau\& Sellers (2002) investigates the Spanish stock market's reaction to quality certification over the period (1993-1999. Using event study methodology, findings show that Spanish stock market reacts positively to the announcement of ISO certification, ISO could be a useful for reducing asymmetry information among buyers and sellers and certification leads to increase in Firm's market value.

Chua et al (2003) investigates the impact of ISO 9000 certification on business performance, as applied on Singapore stock exchange. The study surveyed companies' perception of ISO's impact on business performance. The sample size comprised of 146 companies from the board of stock exchange covering a period (1987-1997). Results indicate that ISO 9000 certification improved financial performance.

Naser et al (2004) investigates the impact of ISO registration on companies' financial performances, using a sample of 81 ISO Malaysian certified companies and 81 non ISO companies, during the period 1996-2001. Results indicate that ISO registration enhance return on sales (ROS) and economic value added (EVA).

Corbett et al (2005) tests the effect of ISO certification on ROA (return on assets) \& ROS (return on sales). An event study methodology is adapted for the study using Global registry of ISO 9000 certifications and Compusat annual industrial file data for 1987-1997. The study show strong indicators that firms after seeking ISO 9000 certification make changes that lead to improvements in ROA through increased productivity.

In contrast to the studies reporting business benefits, Terziovski et al (1997) investigates 1000 firms in Australia and New Zealand and finds that QCert has no significant, positive impact on business performance. Also, Caruana \& Pitt (1997) covers 131 UK service firms, and suggests that better quality does have a positive effect 
on the overall performance of the firm, relative to its competitors. Event studies by Lima et al. (2000) and Martínez-Costa\& Martínez-Lorente (2002) find no effects in Brazil and Spain respectively.

Regarding other quality accreditation, Hendricks\& Singhal (2001) uses event studies to show that winning a quality award increases stock price and operating performance.

The effects of cross listing on financial performance have been addressed by many researchers. Shah (2000) relates the experience of abnormal returns on the Bombay stock exchange surrounding the pricing date of GDR issues by Indian firms. Results find that the extent of mispricing has dropped sharply, where the highest point in the average cumulative returns, in excess of the market index over the weeks preceding the pricing date have dropped from $18.9 \%$ (for the 20 GDR issues before 15 May 1994) to $6.9 \%$ (for the 26 GDR issues after this date).

Kadapakkam \& Misra (2003) examines the linkages between returns on Indian Global Depositary Receipts (GDRs) in London and their underlying stocks in India. Although arbitrage is not feasible for GDRs that sell at a premium, these GDRs are, nevertheless, sensitive to Indian returns. GDR returns have a significant but small effect on subsequent returns of the underlying stocks, with more liquid GDRs having a slightly greater impact.

Kumar (2006) assesses the impact of listing of ADRs and GDRs on the returns of the firm's underlying domestic shares by using a sample of 68 Indian DR programs that listed on the foreign markets between 1st January, 1996 and 30th June, 2001. Result indicate that GDR listings adversely affects the returns, ADR listings do not seem to have any significant impact on the returns available from the underlying domestic shares.

Dodd \& Louca (2012) evaluates the relationship between international cross-listings and shareholders' wealth across different host markets and across time. For a sample of cross-listings by European companies in the US, in the UK, and within Europe, the findings show that US and UK cross-listings, on average, result in positive cumulative abnormal returns around the announcement of cross-listing. No such evidence exists for the rest of European cross-listings. In addition, the Sarbanes-Oxley Act (SOX) of 2002 affects negatively the wealth benefits of US cross-listings, while wealth creation around UK cross-listings is primarily concentrated in Alternative Investment Market listings rather than Main Market listings.

Using a sample of Canadian firms that cross-listed on U.S. stock exchanges, Vemala et al (2013) finds that cross-listing has a significant positive influence on CEO compensation. CEOs receive significantly greater compensation after cross-listing compared to what they are paid before cross-listing. Results, also, show that firm size and board independence positively influence CEO compensation, while CEO duality does not have any significant influence.

Comparing with previous work, the current study tries to:

1) Investigate both international and national accreditation effects on financial performance of listed companies, while previous work tend to address only one type.

2) Evaluate the impact of having quality competitive advantages, not only through ISO accreditation but also by having other award, as an international accreditation.

3) Address the impact of having quality competitive advantages, not only by cross listing as GDR but also by listing in S\&P/EGX ESG, as a national accreditation.

\section{Developing Hypotheses \& Research Methodology}

The research aims at testing the following hypotheses:

1) There's no significant difference of stocks' abnormal returns of Egyptian listed companies before announcement of having international quality competitive advantages, compared with those of after these events.

2) There's no significant difference of stocks' abnormal returns of Egyptian listed companies before announcement of having national quality competitive advantages, compared with those of after these events.

Regarding the anticipated impact of ISO certification, it's argued that it may vary from one country to another; this is because ISO has been viewed from different angles. It is looked up as a step forward towards customers' satisfaction Gano (2001); a way to achieve competitive advantage Casadesús et al. (2000) and Wayhan et al. (2002), and a way for organizations to enter the knowledge edge of the century Tsim et al. (2002).

Regarding the anticipated impact of cross-listing, Coffee (2002) argues that cross-listing firms are significantly different from firms in the same jurisdiction that do not cross-list, most notably in that the former have higher growth prospects and are willing to sacrifice some of the private benefits of control to obtain equity finance. Conversely, firms that do not cross-list typically have controlling shareholders who have less interest in stock 
market valuation because they anticipate selling only in a control transaction at a control premium that they will disproportionately capture.

Regarding the anticipated impact of listing in S\&P/EGX ESG index, the Environment, Social and Governance (ESG) Index for Egypt has been created by the Egyptian Institute of Directors, under the guidance of Standard \& Poor's. The purpose of this index is to raise the profile of those companies that perform well along the three parameters of environmental, social and corporate governance responsibility when compared to their market peers.

Research population includes all events of quality competitive advantages, which have been announced by listed companies in the Egyptian exchange market index (EGX30) through the period from the beginning of 2006 to the end of 2012. The date of the announcement of the event has been identified by the first day by which the information has been available to the investors, weather by publishing at newspapers or uploading at the web site of the Egyptian Exchange. Table (2) indicates these 16 companies and shows that 9 of them have been listed in S\&P/EGX ESG index as follows:

Table 1. Companies listed in EGX30 and in S\&P/EGX ESG

\begin{tabular}{llc}
\hline No. & \multicolumn{1}{c}{ Company's Name } & S\&P/EGX ESG \\
\hline 1 & Orascom for Constructions & $\checkmark$ \\
2 & Commercail International Bank (Egypt) & $\checkmark$ \\
3 & Egyptain Kuwaiti Holding & $\checkmark$ \\
4 & Telecom Egypt & \\
5 & E-F-G Hermes & \\
6 & National Societe Generale Bank (NSGB) & $\checkmark$ \\
7 & Ezz Steel & $\checkmark$ \\
8 & Alexandria Mineral Oils & $\checkmark$ \\
9 & Sidi Kirir Petrochemicals & $\checkmark$ \\
10 & Six of October for Development \& Investment & \\
11 & Egyptain for Tourism Resorts & \\
12 & Arab Cotton Ginning & \\
13 & Egyptain Financail \& Industies & \\
14 & Cairo Investment \& Real Estat Development & $\checkmark$ \\
15 & Raya Holding & $\checkmark$ \\
16 & Delta for Reconstruction \& Development & \\
\hline
\end{tabular}

Research population includes 34 events of announcement regarding having quality competitive advantages. After excluding noisy actions, the research sample includes 11 events.

Event study methodology is an important tool for analyzing abnormal returns that result in announcements of different corporate actions. Prior to Fama et al (1969), Ball \& Brown (1968) introduced the "foundations of methodology" and "information content of earnings", which indicates the effect of earnings announcement upon abnormal returns. Beaver (1968) and Christie (1982) discuss earnings announcement. Also, Brown\& Warner $(1980 ; 1985)$ suggest basic modifications in the methodology to handle complications due to violations of certain statistical assumptions. This has been more elaborated by MacKinaly (1997).

Many other scholars explored the event study methodology, where Ohlson\& Penman (1985) and (David, 1987) analyze split announcement, Pound\& Zechhauser, (1990) addresses the impact of takeover rumors and Fama (1998) illustrates the behavior abnormal returns during the event window and shows how long-term return anomalies tend to disappear with reasonable changes in techniques of event study.

Cummins \& Lewis (2003) investigates the effect of September 11, 2001 terrorism. Also, Fatum \& Hutchison (2006) examines the impact of foreign exchange market intervention operations in Japan. Using sign test and matched sample test, strong evidence is found that sterilized intervention systemically affects the exchange rate in the short run. Muradoğlu\& Aydoğan (2003) shows that stock dividends and right offerings announcements may lead to significant positive abnormal returns at the Istanbul Stock Exchange over the period 1993-1994.

Jones \& Danbolt (2004) analyses the announcement of investment expenditures, while Schultz (2004) and Wang (2005) study the announcement of dividends. Also, Scoltnes\& Wit (2004) examines the announcement effects of bank merger in Europe and the US. 
The two hypotheses could be tested using Event Study technique, through the following steps:

1-C alculating the actual return of stock $i$ at time $\mathrm{t}$, as follows

$$
R_{i, t}=\left(P_{i, t^{-}} P_{i, t-1}\right) / P_{i, t-1}
$$

2-Calculating the market return of stock i at time t, as follows:

$$
R_{m, t}=\left(M_{m, t^{-}} M_{m, t-1}\right) / M_{m, t-1}
$$

3-Calculating the estimated return of stock i at time t, using "market model", as follows:

$$
\dot{R}_{i, t}=\alpha_{i}+\beta_{i} R_{m, t}
$$

4-Estimating the abnormal return (and cumulative abnormal return) of stock i at time t, as follows:

$$
\begin{gathered}
A R_{i, t}=R_{i, t}-\dot{R}_{i, t} \\
C A R_{i, t}=\sum_{t=1}^{n} A R_{i, t}
\end{gathered}
$$

5-Testing significance between abnormal returns (and cumulative abnormal returns) within the event window, where:

$\mathrm{P}_{\mathrm{it}}$ : Price of share $\mathrm{i}$ at the end of period $t$.

$\mathrm{P}_{\mathrm{it}-1}$ : Price of share $\mathrm{i}$ at the end of period $\mathrm{t}-1$.

$\mathrm{M}_{\mathrm{t}}$ : Market index (EGX30) at the end of period $\mathrm{t}$.

$\mathrm{M}_{\mathrm{t}-1}$ : Market index (EGX30) at the end of period $\mathrm{t}-1$.

$\widehat{R}_{i t}$ : Normal return of stock $\mathrm{i}$ at time $\mathrm{t}$ (predicted using the market model).

$\mathrm{AR}_{\mathrm{it}}$ : Abnormal return of stock $i$ at time $\mathrm{t}$

\section{Results of Empirical Work}

Abnormal Return (AR) expresses the difference between the actual and expected (normal) return while Cumulative Abnormal Return (CAR), is the sum of all abnormal returns during the event window. Abnormal Return may be triggered by corporate events, where positive ARs indicate that the market reacts positively to the informational content regarding competitive advantages.

Event study methodology is used to test the significance of differences among ARs and CARs through the following steps:

\subsection{Estimating the Normal Return}

In this step, estimating the normal return is performed using the market model with an estimation period of (-40: $-11)$.

4.2 Estimating Abnormal Return "AR" and "CAR"

Abnormal Returns and Cumulative Abnormal Returns for the 11 events are calculated.

\subsection{Testing the Normality of ARs and CARs}

The following table summarizes testing normality using Kolmogrov-Smirnov test:

Table 2. Testing normality of ARs using Kolmogrov-Smirnov test

\begin{tabular}{ccc}
\hline $\boldsymbol{D a y}$ & $\boldsymbol{Z}$ & Sig. \\
\hline-10 & 0.921 & 0.365 \\
-9 & 0.488 & 0.971 \\
-8 & 0.569 & 0.902 \\
-7 & 1.087 & 0.188 \\
-6 & 1.095 & 0.181 \\
-5 & 0.775 & 0.585 \\
-4 & 0.674 & 0.753 \\
-3 & 0.926 & 0.357 \\
-2 & 0.658 & 0.760 \\
-1 & 0.751 & 0.626 \\
0 & 0.620 & 0.837 \\
1 & 0.906 & 0.384 \\
\hline
\end{tabular}




\begin{tabular}{ccc}
\hline 2 & 0.628 & 0.325 \\
3 & 0.646 & 0.798 \\
4 & 0.576 & 0.895 \\
5 & 0.708 & 0.697 \\
6 & 1.150 & 0.142 \\
7 & 0.654 & 0.785 \\
8 & 0.725 & 0.699 \\
9 & 1.139 & 0.150 \\
10 & 1.065 & 0.206 \\
\hline
\end{tabular}

As shown above, all significance levels associated with $\mathrm{Z}$ values indicate that the daily abnormal returns departures from normality. So, nonparametric tests should be used.

\subsection{Testing the Significance of Differences among ARs}

Table (3) illustrates the significance of variation among ARs comparing those of days -10: -1 with those of days 1: 10, using Wilcoxon Signed Rank Test, as follows:

Table 3. Testing significance of differences among abnormal returns

\begin{tabular}{|c|c|c|}
\hline Type of Events & Period & $\mathbf{Z}$ \\
\hline \multirow{11}{*}{ International Accreditation } & Day -10: Day 10 & $0.943(0.345)$ \\
\hline & Day -9 : Day 9 & $1.135(0.249)$ \\
\hline & Day -8 : Day 8 & $1.135(0.249)$ \\
\hline & Day -7 : Day 7 & $1.782(0.075)^{*}$ \\
\hline & Day -6 : Day 6 & $0.943(0.345)$ \\
\hline & Day -5 : Day 5 & $0.734(0.463)$ \\
\hline & Day -4 : Day 4 & $0.000(1.000)$ \\
\hline & Day -3 : Day 3 & $0.314(0.753)$ \\
\hline & Day -2 : Day 2 & $1.992(0.046)^{* *}$ \\
\hline & Day -1 : Day 1 & $1.363(0.173)$ \\
\hline & Day -10: Day 10 & $1.095(0.273)$ \\
\hline \multirow{9}{*}{ National Accreditation } & Day -9 : Day 9 & $0.365(0.715)$ \\
\hline & Day -8 : Day 8 & $0.730(0.465)$ \\
\hline & Day -7 : Day 7 & $1.604(0.109)$ \\
\hline & Day -6 : Day 6 & $1.461(0.144)$ \\
\hline & Day -5 : Day 5 & $1.095(0.273)$ \\
\hline & Day -4 : Day 4 & $0.730(0.465)$ \\
\hline & Day -3 : Day 3 & $0.003(0.989)$ \\
\hline & Day -2 : Day 2 & $1.461(0.144)$ \\
\hline & Day -1 : Day 1 & $1.826(0.068) *$ \\
\hline \multirow{10}{*}{ National and International Accreditation } & Day -10: Day 10 & $0.267(0.790)$ \\
\hline & Day -9 : Day 9 & $0.533(0.594)$ \\
\hline & Day -8 : Day 8 & $0.000(1.000)$ \\
\hline & Day -7 : Day 7 & $0.663(0.508)$ \\
\hline & Day -6 : Day 6 & $1.867(0.062)^{*}$ \\
\hline & Day -5 : Day 5 & $0.533(0.593)$ \\
\hline & Day -4 : Day 4 & $0.845(0.398)$ \\
\hline & Day -3 : Day 3 & $0.089(0.929)$ \\
\hline & Day -2 : Day 2 & $2.134(0.033)^{* *}$ \\
\hline & Day -1 : Day 1 & $0.089(0.929)$ \\
\hline
\end{tabular}

Values between brackets under $\mathrm{Z}$ indicate p-values, where * denotes p-value of $10 \%$, ** denotes p-value of $5 \%$ and $* * *$ denotes p-value of $1 \%$.

As shown above, significance of variation among ARs are shown between (day -2 and day 2) and between (day -7 and day 7) for international accreditation. Also, results indicate significant variations between (day -1 and day 1) for national accreditation. For both of international and national accreditation, results indicate significant variations between (day -2 and day 2 ) and between (day -6 and day 6). This indicates that the Egyptian stock market is more sensitive to announcement of national accreditation than international one, as it reacts rapidly within the period between (day -1 and day 1 ).

\subsection{Testing the Significance of Differences Among CARs}

Table (4) illustrates the significance of variation among CARs comparing those of days -10: -1 with those of 
days 1: 10, using Wilcoxon Signed Rank Test, as follows:

Table 4. Testing significance of differences among cumulative abnormal returns

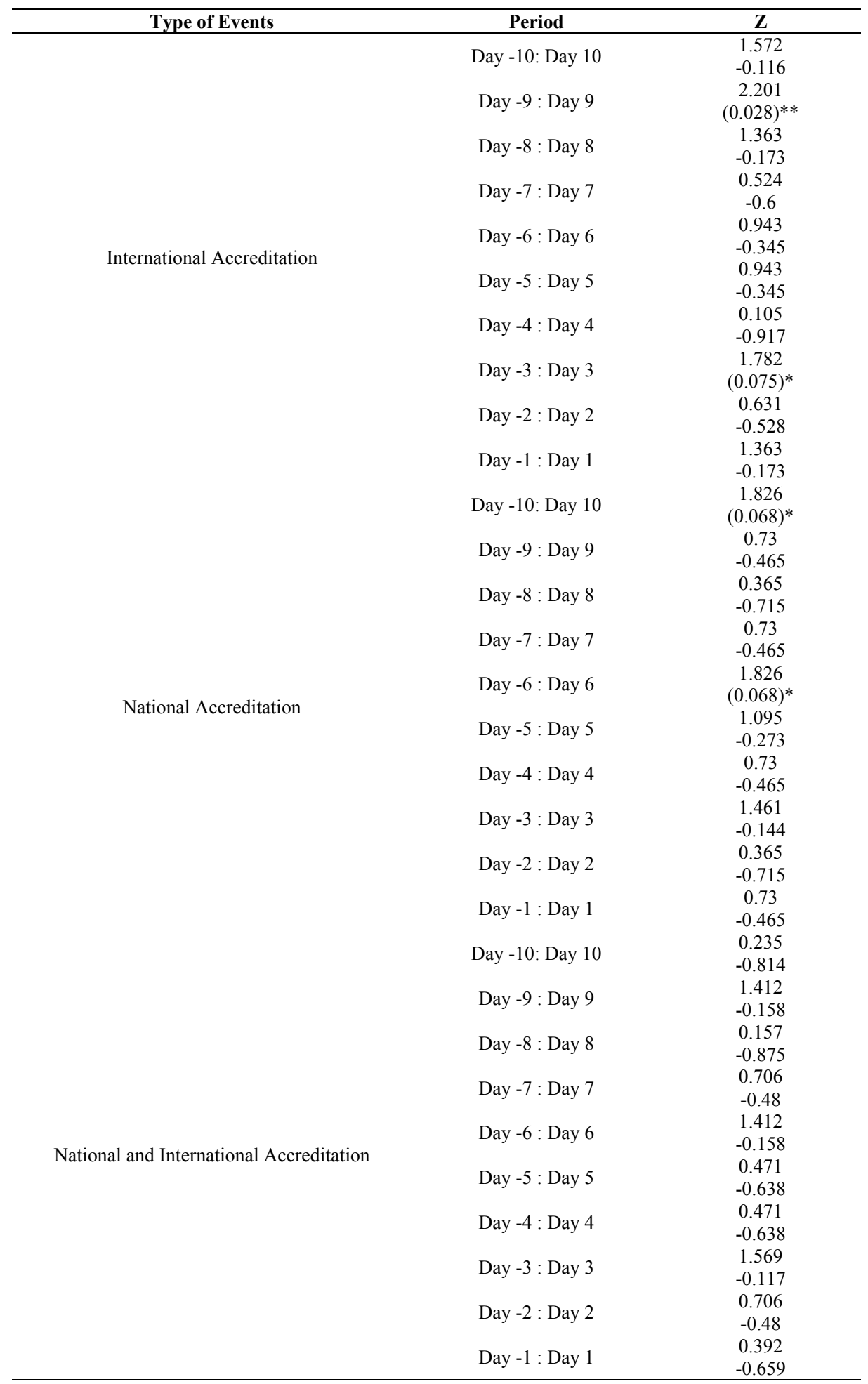

Values between brackets under $\mathrm{Z}$ indicate $\mathrm{p}$-values, where $*$ denotes $\mathrm{p}$-value of $10 \%, * *$ denotes $\mathrm{p}$-value of $5 \%$ and $* * *$ denotes $\mathrm{p}$-value of $1 \%$.

As shown above, significance of variation among CARs are shown between (day -3 and day 3 ) and between (day -9 and day 9) for international accreditation. Also, results indicate significant variations between (day -6 and day 
6) and between (day -10 and day 10) for national accreditation, and show positive market reactions to these informational contents.

\section{Summary and Concluded Remarks}

This paper investigates the impact of having quality competitive advantages, concerning with ISO accreditation and other quality awards (as international accreditation). Also, it tries to address the effect of cross listing and listing in S\&P/EGX ESG (as national accreditation). This evaluation is conducted for listed companies in Egyptian exchange.

The research aims at testing the following two hypotheses: 1) there's no significant difference of stocks' abnormal returns of Egyptian listed companies before announcement of having national quality competitive advantages, compared with those of after these events. 2) there's no significant difference of stocks' abnormal returns of Egyptian listed companies before announcement of having international quality competitive advantages, compared with those of after these events.

Research population includes all events of announcement regarding quality competitive advantages, which have been announced by listed companies in the Egyptian exchange market index (EGX30) through the period from the beginning of 2006 to the end of 2012. So, the research population includes 34 events, while research sample includes 11 events after excluding noisy actions.

Using event study methodology, results indicate that null hypothesis should be rejected and alternative one may be accepted for both of research hypotheses. Robustness checks have been performed, as follows:

1) Wilcoxon Signed Rank test is conducted (covering the events of both national and international accreditation) and results have been assured.

2) Wilcoxon Signed Rank test is conducted (as applied on ARs) and results have assured the findings conducted using CARs.

In brief, results indicate that informational content of competitive advantages has a positive effect on abnormal return of listed companies in the Egyptian exchange.

\section{References}

Aarts, M., \& Vos, E. (2001). The impact of ISO registration on New Zealand firms performance: A financial performance. The TQM Magazine, 13(3), 180-91. http://dx.doi.org/10.1108/09544780110384871

Ball, R., \& Brown, P. (1968). An empirical evaluation of accounting income numbers. Journal of Accounting Research, 6(2), 159-178. http://dx.doi.org/10.2307/2490232

Beaver, W. (1968). The information content of annual earnings announcement. Journal of Accounting Research, 6, 67-92. http://dx.doi.org/10.2307/2490070

Brown, S., \& Warner, J. (1980). Measuring security price performance. Journal of Financial Economics, 8, 205-58. http://dx.doi.org/10.1016/0304-405X(80)90002-1

Brown, S., \& Warner, J. (1985). Using daily stock returns: The case of event studies. Journal of Financial Economics, 14, 3-31. http://dx.doi.org/10.1016/0304-405X(85)90042-X

Caruana, A., \& Pitt, L. (1997). An internal measure for service quality and the link between service quality and business performance. European Journal of Marketing, 31(4), 604-617. http://dx.doi.org/10.1108/03090569710176600

Casadesús, M., Heras, I., \& Ochao. (2000). The benefits of the implementation of the ISO 9000 normative: Empirical research in the Spanish companies. The 1st. World Conference on Production and Operations Management (POM). Seville.

Central Bank of Egypt. (2011). Monthly Statistical Bulletin, 173.

Chapman, R., Murray, P., \& Mellor, R. (1997). Strategic quality management and financial performance indicators. International Journal of Quality and Reliability Management, 14(4), 432-448. http://dx.doi.org/10.1108/02656719710170675

Christie, A. (1982). The stochastic behavior of common stock variance: Value, leverage and interest rate effects. Journal of Financial Economics, 10, 407-432. http://dx.doi.org/10.1016/0304-405X(82)90018-6

Chua, C., Goh, M., \& Wan, T. (2003). Does ISO 9000 certification improve business performance? International Journal of Quality \& Reliability Management, 20(8/9). 
Coffee, J. (2002). Racing towards the top? The impact of cross-listings and stock market competition on international corporate governance. Columbia Law and Economics Working Paper No. 205. http://dx.doi.org/10.2307/1123661

Corbett, C., Montes-Sancho, \& Kirsch, D. (2005). The financial impact of ISO 9000 certification in the United States: An empirical analysis. Management Science, 51(7), $1046-1059$. http://dx.doi.org/10.1287/mnsc. 1040.0358

Corbett, C., \& Kirsch, D. (2001). International diffusion of ISO 14000 certification. Production and Operations Management, 10(3), 327-342. http://dx.doi.org/10.1111/j.1937-5956.2001.tb00378.x

Cummins, J., \& Lewis, C. (2003). Catastrophic events, parameter uncertainty and the breakdown of implicit long-term contacting: The case of terrorism insurance. Journal of Risk and Uncertainty, 26, 153-178. http://dx.doi.org/10.1023/A:1024115107245

David, A. (1987). A note on the behavior of stock returns around ex-dates of stock distributions. Journal of Finance, 42, 163-168. http://dx.doi.org/10.1111/j.1540-6261.1987.tb02558.x

Davis, L. (1997). Quality assurance: ISO 9000 as a Management Tool. Copenhagen.

Deming, W. (1982). Quality, productivity and competitive position. Mass: MIT Cambridge.

Dimara, E., Skuras, D., Tsekouras, K., \& Goutsos, S. (2002). Strategic orientation and financial performance of firms implementing ISO 9000. International Journal of Quality \& Reliability Management, 12(1), $72-89$.

Docking, D., \& Dowen, R. (1999). Market interpretation of ISO 9000 registration. The Journal of Financial Research, 22(2), 147-160.

Dodd, O., \& Louca, C. (2012). International cross-listing and shareholders' wealth. Multinational Finance Journal. Retrieved from http://ssrn.com/abstract=2169675

Easton, G., \& Jarrell, S. (1998). The effects of total quality management on corporate performance: An empirical investigation. Journal of Business, 71(2), 253-307. http://dx.doi.org/10.1086/209744

Elmuti, D., Kathawala, Y., \& Lloyed, S. (1997). The benchmarking process: Assessing its value and limitations. Industrial Management, 40-50.

Fama, E., Fisher, L., Jensen, M., \& Roll, R. (1969). The adjustment of stock prices to new information. International Economic Review, 10, 1-21. http://dx.doi.org/10.2307/2525569

Fama, E. (1998). Market efficiency, long-term returns, and behavioral finance. Journal of Financial Economics, 49(3), 283-306. http://dx.doi.org/10.1016/S0304-405X(98)00026-9

Fatum, R., \& Hutchison, M. (2006). Effectiveness of official daily foreign exchange market intervention operations in Japan. Journal of International Money and Finance, 25(2), $199-219$. http://dx.doi.org/10.1016/j.jimonfin.2005.11.007

Gano, D. (2001). Effective problem solving: A new way of thinking. Proceedings of The World Quality Congress, $110-22$.

Haversjo, H. (2000). The financial effects of ISO 9000 registration for danish companies. Managerial Auditing Journal, 15(1,2), 47-52. http://dx.doi.org/10.1108/02686900010304632

Hendricks, K. B., \& Singhal, V. R. (2001). The long-run stock price performance of firms with effective TQM programs. Management Science, 47(3), 359-368. http://dx.doi.org/10.1287/mnsc.47.3.359.9773

Heras, I., Dick, G. P., \& Casadesus, M. (2002). ISO 9000 registration's impact on sales and profitability. The International Journal of Quality \& Reliability Management, $19(6 / 7)$. http://dx.doi.org/10.1108/02656710210429618

Hesham, M., \& Curry, A. (2003). An empirical analysis of management attitudes towards ISO 9001:2000 in Egypt. The TQM Magazine, 15(6), 381-390. http://dx.doi.org/10.1108/09544780310502714

Jones, E., \& Danbolt, J. (2004). Empirical evidence on the determinants of the stock market reaction to product and market diversification announcement. European Business Management School, Working Paper.

Juran, J. (1982). Juran on Quality Improvement. New York: Juran Institute.

Kadapakkam, P., \& Misra, L. (2003). Return linkages between dual listings under arbitrage restrictions: A study of Indian stocks and their London global depositary receipts. Financial Review, 38(4). http://dx.doi.org/10.1111/1540-6288.00063 
Kumar, M. (2006). The impact of Indian overseas listings on the returns of the underlying shares. Retrieved from http://ssrn.com/abstract $=951368$

Lee, K., \& Palmer, E. (1999). An empirical examination of ISO 9000 registered companies in New Zealand. Total Quality Management, 10(6), 887-899. http://dx.doi.org/10.1080/0954412997307

Lima, M., Resende, M., \& Hasenclever, L. (2000). Quality certification and performance of Brazilian firms: An empirical study. International Journal of Production Economics, (66), 143-147. http://dx.doi.org/10.1016/S0925-5273(99)00118-8

MacKinlay, C. (1997). Event studies in economics and finance. Journal of Economic Literature, 35(1), 13-39.

Martínez-Costa, M., \& Martínez-Lorente, A. (2002). Effects of the ISO 9000 certification on the firm's performance: A vision from the market.

McGrath, R. (2013). The end of competitive advantage: How to keep your strategy moving as fast as your business. Boston: Harvard Business Review Publishing.

Mo, J., \& Chan, A. (1997). Strategy for the successful Implementation of ISO 9000 in small and medium manufacturers. The TQM Magazine, 9(2), 135-145. http://dx.doi.org/10.1108/09544789710165581

Muradoğlu, G., \& Aydoğan, K. (2003). Trends in market reactions: Stock dividends and rights offerings at Istanbul stock exchange. European Journal of Finance, 9(1), 41-60. http://dx.doi.org/10.1080/13518470110047611

Naser, K., Karbhari, Y., \& Mokhtar, M. (2004). Impact of ISO 9000 registration on company performance: Evidence from Malaysia. Managerial Auditing Journal, 19(4), 509-516. http://dx.doi.org/10.1108/02686900410530510

Nicolau, J., \& Sellers, R. (2002). The stock market's reaction to quality certification: Empirical evidence from Spain. European Journal of Operational Research, 142, 632-641. http://dx.doi.org/10.1016/S0377-2217(01)00312-5

Ohlson, J., \& Penman, S. (1985). Volatility increases subsequent to stock splits: An empirical aberration. Journal of Financial Economics, 14, 251-266. http://dx.doi.org/10.1016/0304-405X(85)90017-0

Porter, M. (1980). Competitive Strategy. NY: Free Press.

Pound, J., \& Zechhauser, R. (1990). Clearly heard on the street: The effect of takeover rumors on stock prices. Journal of Business, 63, 291-308. http://dx.doi.org/10.1086/296508

Rao, S., Ragu-Nathan, T., \& Solis, L. (1997). Does ISO 9000 have an effect on quality management practices? An international empirical study. Total Quality Management, 8(6), 335-346. http://dx.doi.org/10.1080/0954412979352

Sandholm, L. (2000). Quality in developing countries (5th ed.). NY: McGraw-Hill.

Scholtens, B., \& Wit, R. (2004). Announcement effects of bank mergers in Europe and the US. International Business and Finance, 18(2). http://dx.doi.org/10.1016/j.ribaf.2004.04.002

Schultz, J. (2004). Interpreting good and bad news signals: The effects of dividend initiations on stock price returns. Retrieved from www.woodrow.mpls.frb.fed.us/mea/papers/Schultz-term-2004.pdf

Shah, A. (2000). The tale of one market inefficiency: Abnormal returns around GDR issues by Indian firms. Retrieved from http://ssrn.com/abstract=6183

Terziovski, M., Samson, D., \& Dow, D. (1997). The business value of quality management systems certification: Evidence from Australia and New Zealand. Journal of Operations Management, 15(1), 1-18. http://dx.doi.org/10.1016/S0272-6963(96)00103-9

Tsim, C., Yeung, S., \& Leung, C. (2002). An adaptation to ISO 9001:2000 for Certified Organizations. Managerial Auditing Journal, 17(5), 245-250. http://dx.doi.org/10.1108/02686900210429669

Vemala, P., Brusa, J., Omar, R., \& Camacho, P. (2013). The effect of cross-listing on CEO compensation. Journal of International Financial Studies, Forthcoming. Retrieved from http://ssrn.com/abstract=2192162

Wang, Y. (2005). The effect of dividend initiations on stock returns: A propensity score matching approach. Retrieved from www.chass.utoronto.ca/ yanwang/dividend.p

Wayhan, V., Kirche, E., \& Khumawala, B. (2002). ISO 9000 certification: The financial performance implications. Total Quality Management, 13(2), 217-231. http://dx.doi.org/10.1080/09544120120102450 


\section{Copyrights}

Copyright for this article is retained by the author(s), with first publication rights granted to the journal.

This is an open-access article distributed under the terms and conditions of the Creative Commons Attribution license (http://creativecommons.org/licenses/by/3.0/). 